\title{
Antitumor activity of IHL-305, a novel pegylated liposome containing irinotecan, in human xenograft models
}

\author{
TAKESHI MATSUZAKI $^{1}$, AKIMITSU TAKAGI $^{1}$, TOMIO FURUTA $^{1}$, SATOSHI UENO $^{1}$, AKINOBU KURITA $^{1}$, \\ GOU NOHARA $^{2}$, HIROSHI KODAIRA ${ }^{2}$, SEIGO SAWADA ${ }^{1}$ and SHUSUKE HASHIMOTO ${ }^{1}$ \\ ${ }^{1}$ Yakult Central Institute for Microbiological Research, Yakult Honsha Co., Ltd., 1796 Yaho, Tokyo 186-8650; \\ ${ }^{2}$ Pharmaceutical Development Department, Yakult Honsha Co., Ltd., 16-21 Ginza 7-chome, Tokyo 104-0061, Japan
}

Received June 7, 2011; Accepted July 27, 2011

DOI: $10.3892 / o r .2011 .1465$

\begin{abstract}
The antitumor effect of IHL-305, a novel pegylated liposome containing irinotecan, was investigated in human xenograft models. After subcutaneous transplantation of several human cancer cell lines (colorectal, non-small cell lung, small cell lung, prostate, ovarian and gastric cancer cells) to nude mice, IHL-305 or CPT-11 was administered intravenously 3 times at 4 -day intervals. In all xenograft models tested, IHL-305 showed superior antitumor activity to that of CPT-11 and a comparable tumor-growth-inhibitory effect at one-eighth or less of the dose of CPT-11, even against HT-29 colorectal and NCI-H460 non-small cell lung cancer cell lines, which show intrinsic resistance to CPT-11. A single injection or 2 injections of IHL-305 on several dosing schedules also resulted in a significant antitumor effect compared to that of vehicle control in a dose-dependent manner and showed comparable antitumor activity at about one-fifth the dose of the maximum tolerated dose of CPT-11. The analysis of the concentrations of irinotecan and SN-38, an active metabolite of CPT-11, in plasma and tumors revealed that irinotecan was maintained at high concentrations, and the prolonged presence of SN-38 in plasma and tumors in IHL-305 treated mice compared with CPT-11-treated mice. Therefore, the stronger tumor inhibitory effect of IHL-305, as compared to CPT-11, was associated with the difference in the concentration of irinotecan in plasma or tumors after each agent was administered and with the maintainance of a higher concentration of SN-38. These results indicate that IHL-305 demonstrated superior antitumor activity against a wide range of tumors at lower doses than CPT-11.
\end{abstract}

Correspondence to: Dr Akimitsu Takagi, Yakult Central Institute for Microbiological Research, Yakult Honsha Co., Ltd., 1796 Yaho, Kunitachi-shi, Tokyo 186-8650, Japan

E-mail: akimitsu-takagi@yakult.co.jp

Key words: irinotecan, liposome, antitumor activity, pharmacokinetics

\section{Introduction}

Irinotecan hydrochloride (CPT-11) was semi-synthesized from 20(S)-Camptothecin which is an alkaloid isolated from Camtotheca acuminata (1). CPT-11 has been demonstrated to possess strong antitumor activities in preclinical studies against various kinds of experimental tumors both in vitro $(2,3)$ and in vivo $(4,5)$. In recent years, CPT-11 is being widely used clinically as one of the key drugs for standard chemotherapy against colorectal cancer due to its confirmed evidence of antitumor efficacy (6-8). Side effects such as myelosuppression or diarrhea, which are the dose-limiting toxicities of CPT-11, have however been reported, and have also been observed in clinical use $(9,10)$. Therefore, many approaches have been tried to alleviate the side effects by reducing the dosage (11) or modifying the formulation of CPT-11 $(12,13)$.

IHL-305 is a preparation of irinotecan encapsulated in polyethylene glycol (PEG)-modified liposomes (14). In general, liposome preparations are known to be selectively transported to tumor tissues due to their enhanced permeability and retention (EPR) (15-17), leading to the reduction of toxicity and augmentation of cytotoxicity in the target cells. For the past few years, numerous studies regarding liposome preparations have been conducted using anticancer agents such as doxorubicin (18-20), cisplatin $(21)$, taxol $(22,23)$ or camptothecin $(24,25)$ in preclinical as well as in clinical trials. As one of constructed carriers, liposomes with a PEG coating have proved to be very successful as a drug carrier system. Recent pharmacokinetics and therapeutic studies reveal that sterically stabilized liposomes have considerable potential as drug carriers and the modification of some liposome preparations with PEG has improved their stability in the blood, resulting in better clinical results (12). For example, Doxil is a long-circulating pegylated liposomal preparation containing doxorubicin (DXR) which has been approved for clinical use in the treatment of cancers including phase I-II randomized trials $(26,27)$. As one of their reported characteristics, liposomes exhibit reduced clearance or a prolonged plasma half-life due to the so-called stealth effect, by which they are not recognized by the reticuloendothelial systems (28). The potency of anticancer agents is thus expected to be improved by their modification using these carriers. 
The aim of this study was to evaluate the in vivo antitumor activities of a newly formulated pegylated liposomal preparation, IHL-305. In this study, the antitumor efficacy profiles of IHL-305 were examined in comparison with that of CPT-11 using nude mice subcutaneously transplanted with various human cancer cell lines. To elucidate the differences of the antitumor activity, the concentrations of irinotecan and SN-38, which is the active metabolite of CPT-11, was also determined in plasma and tumors after intravenous (i.v.) injection of IHL-305.

\section{Materials and methods}

Drugs. IHL-305 and irinotecan hydrochloride (CPT-11) were obtained from Terumo Corp. (Kanagawa, Japan) and Yakult Honsha Co., Ltd. (Tokyo, Japan), respectively. The components of IHL-305 are irinotecan, cholesterol, hydrogenated soybean phosphatidyl choline, PEG5000-DSPE, ammonium sulfate, sucrose, L-histidine, dilute hydrochloric acid, water for injection, and dehydrated alcohol. IHL-305 liposomes range in diameter from 70-120 $\mathrm{nm}$. The dose of IHL-305 is represented as the amount of irinotecan encapsulated in liposomes.

Animals. Inbred specific pathogen-free 5-6-week-old male BALB/c nude mice were purchased from Japan Charles River Co., Ltd., (Yokohama, Japan) and CLEA Japan, Inc. (Tokyo, Japan). The mice were kept in plastic cages, given a standard diet (MF, Oriental Yeast Industry Co., Tokyo, Japan) and were allowed free access to water. The temperature and humidity were kept at $24 \pm 1^{\circ} \mathrm{C}$ and $55 \pm 10 \%$, respectively.

Cells and culture. The human colorectal cancer cell lines (HCT116, HT-29), non-small cell lung cancer cell line (NCIH460), small cell lung cancer cell line (NCI-H82), prostate cancer cell line (PC-3) and ovarian cancer cell line (ES-2) were purchased from American Type Culture Collection (ATCC, USA). HCT116, HT-29, NCI-H460 and PC-3 were maintained in Dulbecco's modified Eagle's medium (Sigma, MO, USA) containing 10\% heat-inactivated fetal bovine serum (FBS). ES-2 was maintained in McCoy's 5A medium (Sigma) containing $100 \mathrm{units} / \mathrm{ml}$ penicillin, $100 \mu \mathrm{g} / \mathrm{ml}$ streptomycin, $1.5 \mathrm{mM} \mathrm{L}$-glutamine and $10 \%$ heat-inactivated FBS. NCI-H82 was maintained in RPMI-1640 medium (Nissui Pharmaceutical Co., Ltd., Tokyo, Japan) containing 10\% heatinactivated FBS. The human gastric cancer cell line (MKN45) was purchased from Japan Health Sciences Foundation (JHSF, Tokyo, Japan) and was maintained in RPMI-1640 medium containing 100 units $/ \mathrm{ml}$ penicillin, $100 \mu \mathrm{g} / \mathrm{ml}$ streptomycin and $10 \%$ heat-inactivated FBS. All cancer cell lines described above were subcultured serially in vitro and adjusted to the appropriate concentrations before use. The human nonsmall cell lung cancer cell line (QG-56), a gift from Daiichi Pharmaceutical Co., Ltd. was also used, and was maintained by in vivo passages.

Antitumor experiments. After transplanting human cancer cells or fragments subcutaneously to the inguinal region of nude mice, the mice were grouped (5-6 mice/group) on the day when the estimated tumor volume calculated by the following formula (A) reached about $40-220 \mathrm{~mm}^{3}$ (Day 0). IHL-305 or CPT-11 was administered intravenously (i.v.) 1-3 times at intervals of 4-14 days. Physiological saline or empty liposomes were administered as negative controls with the same administration schedule. Tumors were excised on Days 21 or 35, and tumor growth inhibition rate [IR (\%), formula (B)] was calculated from tumor weights. During the study, the long and short diameters of the tumor and body weight of the mice were measured.

(A) Estimated tumor volume $=1 / 2 \times$ long diameter $\mathrm{x}$ short diameter $\mathrm{x}$ short diameter. (B) IR\% $=(1-$ mean tumor weight in the IHL-305 or CPT-11 group/mean tumor weight in the control group) $\mathrm{x} 100$.

All in vivo antitumor experiments were performed according to our internal and ethics committee regulations.

Sample preparation. Blood and tumors were collected at 1 , 3, 6, 24, 48, 72 and $96 \mathrm{~h}$ after i.v. administration of IHL-305 $(45 \mathrm{mg} / \mathrm{kg})$ and CPT-11 $(90 \mathrm{mg} / \mathrm{kg})$ into nude mice. Blood was taken by cardiac puncture under ether anesthesia, after which the tumor was removed from the inguinal region. The blood sample was immediately centrifuged at $0^{\circ} \mathrm{C}$ for $30 \mathrm{sec}$ at $15,000 \mathrm{rpm}$ to separate the plasma. The plasma was diluted 5-fold with $0.15 \mathrm{M} \mathrm{H}_{3} \mathrm{PO}_{4}$ and divided into two aliquots. One aliquot of the plasma mixture was ultra-centrifuged at $10^{\circ} \mathrm{C}$ for $30 \mathrm{~min}$ at $100,000 \mathrm{x} \mathrm{g}$, after which $0.05 \mathrm{ml}$ of the upper layer was added to $0.45 \mathrm{ml}$ of the internal standard (IS) solution $\left(0.1 \mu \mathrm{g} / \mathrm{ml}\right.$ camptothecin in $0.15 \mathrm{M} \mathrm{H}_{3} \mathrm{PO}_{4}$ ) (analytical sample for the determination of irinotecan and SN-38). The other aliquot of the plasma mixture was diluted with a 10 -fold volume of methanol, and then $0.1 \mathrm{ml}$ of the mixture was added to a 4-fold volume of the IS solution (analytical sample for the determination of irinotecan in the IHL-305 group). For each measurement, $0.1 \mathrm{ml}$ was used. The tumors were minced and weighed, and then added to an equal volume of $0.15 \mathrm{M} \mathrm{H}_{3} \mathrm{PO}_{4}$ and an 8 -fold volume of methanol, and then homogenized on ice with a teflon homogenizer. After centrifugation at $0^{\circ} \mathrm{C}$ for $15 \mathrm{~min}$ at $3,000 \mathrm{rpm}, 50 \mu 1$ of the supernatant was added to $0.45 \mathrm{ml}$ of the IS solution (analytical sample for the determination of irinotecan and SN-38). For each measurement, $0.1 \mathrm{ml}$ was used.

Measurement of irinotecan and SN-38 in plasma and tumors. According to the method of Kurita and Kaneda (29), each compound was measured with the HPLC system with a fully automated online solid-phase extraction system (PROSPEKT2; Spark Holland, Emmen, The Netherlands). Briefly, $0.1 \mathrm{ml}$ of the plasma and tumor samples was used for the solid phase extraction with a Cartridge-C18 Analytichem (Spark Holland). A C18 reversed-phase column (Symmetry Column C18, 150x4.6 mm I.D., $5 \mu \mathrm{m}$, Waters, Milford, MA) was used at $50^{\circ} \mathrm{C}$ for chromatography. The fluorescence detector $(470$ scanning fluorescence detector; Waters) was set at $380 \mathrm{~nm}$ and $540 \mathrm{~nm}$ for 0-3.8 min for SN-38, and at 373 and $428 \mathrm{~nm}$ for 3.8-8 min for IS and irinotecan. The mobile phase consisted of $0.05 \mathrm{M} \mathrm{KH}_{2} \mathrm{PO}_{4}$ :acetonitrile (70:30, v/v) containing $4 \mathrm{mM}$ sodium 1-decanesulfonate $\left(\mathrm{pH} 3.5\right.$ with $\left.\mathrm{H}_{3} \mathrm{PO}_{4}\right)$ and the flow rate was $1.5 \mathrm{ml} / \mathrm{min}$. The quantification limits of irinotecan and SN-38 were 5 and $1 \mathrm{ng} / \mathrm{ml}$ for plasma, and 50 and $5 \mathrm{ng} / \mathrm{g}$ for tumor, respectively. 
A
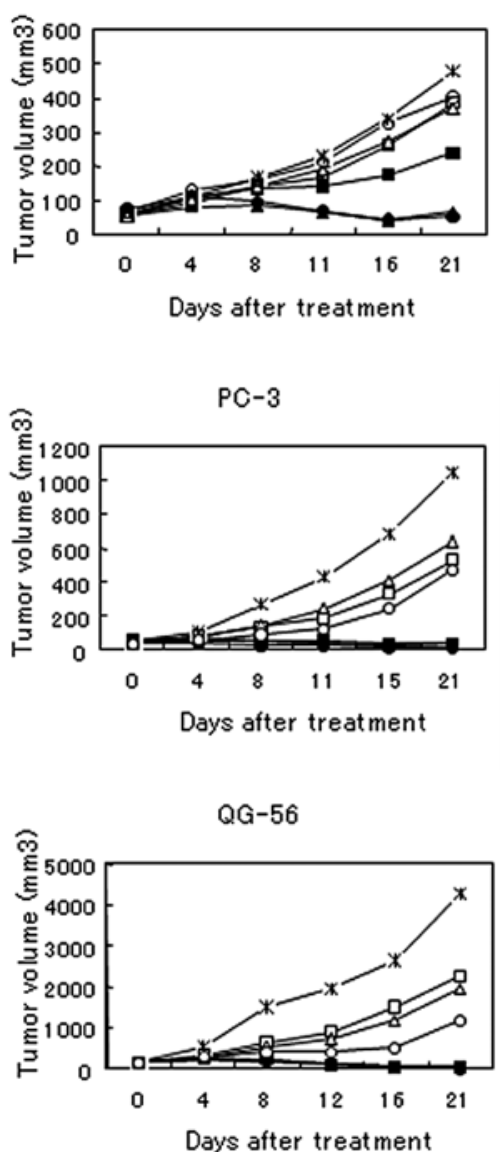

B

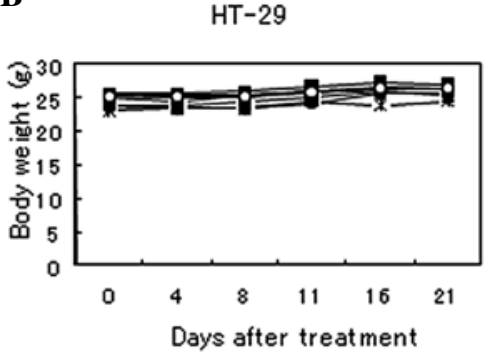

$\mathrm{PC}-3$

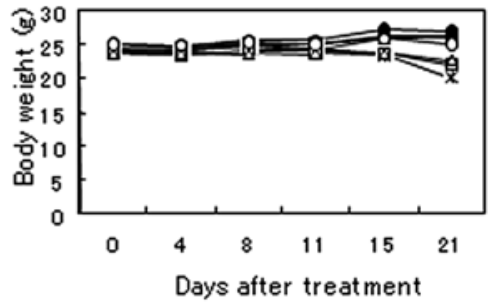

QG-56

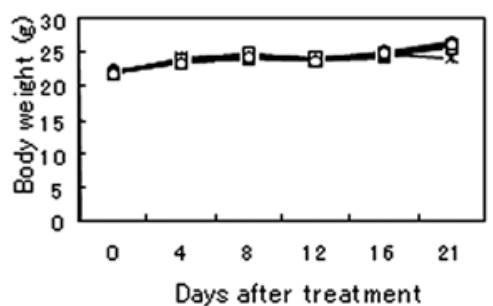

Figure 1. Antitumor activity of IHL-305 and CPT-11 in HT-29-, PC-3- and QG-56-bearing nude mice. After HT-29, PC-3 or QG-56 cells were inoculated subcutaneously into nude mice, the mice were grouped (5-6 mice/group) on the day when their mean estimated tumor volume reached about $40-130$ mm ${ }^{3}$ (Day 0). IHL-305 (घ, $25 \mathrm{mg} / \mathrm{kg} ; \boldsymbol{\Delta}, 50 \mathrm{mg} / \mathrm{kg} ; \bullet, 100 \mathrm{mg} / \mathrm{kg}$ ) and CPT-11 ( $\square, 25 \mathrm{mg} / \mathrm{kg} ; \Delta, 50 \mathrm{mg} / \mathrm{kg} ;$, $100 \mathrm{mg} / \mathrm{kg}$ ) was administered intravenously on Days 1 , 5 and 9 , and the long and short diameter of tumors were monitored. Control (*) was injected with saline. The tumors were excised on Day 21 and the inhibition rate (IR\%) of tumor growth was calculated from tumor weights. (A) Estimated tumor volume, (B) body weight.

Statistical analysis. Among the results obtained, the data of the tumor weight were analyzed statistically using Bonferroni's or Dunnett's multiple comparison test.

Ethics in animal experiments. All the in vivo experimental protocols were approved by the animal care committee of the Yakult Central Institute for Microbiological Research.

\section{Results}

Antitumor effect of IHL-305 against HT-29, PC-3 and QG-56. In a preliminary study, the antitumor effect of IHL-305 was compared with that of CPT-11 against HT-29, PC-3 and QG-56bearing nude mice. Once tumors were established (mean tumor volume, $40-130 \mathrm{~mm}^{3}$ ) in mice transplanted subcutaneously with each tumor, IHL-305 (25, 50 or $100 \mathrm{mg} / \mathrm{kg}$ as irinotecan) or CPT-11 $(25,50$ or $100 \mathrm{mg} / \mathrm{kg})$ was administered intravenously (i.v.) 3 times at 4-days interval (Days 1,5 and 9) to the mice. The inhibition rate (IR) of tumor growth was calculated from tumors excised and weighed on Day 21. Fig. 1A shows the growth curve of each tumor in mice treated with IHL-305 and CPT-11, and all tumors in the control group grew progressively. Changes in body weight are shown in Fig. 1B. As indicated in Tables I-III, IHL-305 showed significant $(\mathrm{p}<0.001)$ tumor growth inhibitory effects in all tumors tested at all doses used in this study. In particular, the IR for IHL-305 tested in PC-3-bearing mice was 99.2-99.5\% with complete regression of tumor in 1 of 5 mice in the $100 \mathrm{mg} / \mathrm{kg}$ group, whereas the IR for CPT-11 was 35.5-67.2\%. When comparisons were made at the same dose level, the tumor weight was significantly lower in the IHL-305 group than in the corresponding CPT-11 group.

Antitumor effect of IHL-305 on various cancer cell lines. In the second study, we assessed the antitumor effect of IHL-305 in various tumor-bearing mice. The highest dose of CPT-11 as the reference in this experiment was set at MTD dosing (total $270 \mathrm{mg} / \mathrm{kg}$ ). IHL-305 was administered i.v. to various tumor-bearing mice and the subsequent tumor growth was monitored for 21 or 35 days. As indicated in Fig. 2A, IHL-305 effectively suppressed the tumor growth of HCT116-HT-29and NCI-H460-bearing mice for 21 days. Moreover, IHL-305 showed strong inhibitory effects in MKN45-, NCI-H82- and ES-2-bearing mice for 35 days (Fig. 2B). Comparison of the IR between IHL-305 and CPT-11 at the same dose clearly demonstrated that IHL-305 also showed a higher IR and dosedependent effect (Fig. 3). 
Table I. Antitumor effect of IHL-305 and CPT-11 on human colorectal cancer cell line HT-29 in nude mice.

\begin{tabular}{|c|c|c|c|c|c|}
\hline \multirow[b]{2}{*}{ Group } & \multirow[b]{2}{*}{ Total dose ${ }^{\mathrm{a}}(\mathrm{mg} / \mathrm{kg})$} & \multirow{2}{*}{$\begin{array}{l}\text { Tumor weight } \\
(\mathrm{g}, \text { mean } \pm \mathrm{SD})\end{array}$} & \multicolumn{2}{|c|}{ p-value ${ }^{c}$ vs. } & \multirow[b]{2}{*}{$\operatorname{IR}^{\mathrm{d}}(\%)$} \\
\hline & & & Control & CPT-11 & \\
\hline Control & - & $0.46 \pm 0.10$ & - & - & - \\
\hline IHL-305 & 25 & $0.20 \pm 0.09$ & $<0.01$ & $<0.05$ & 55.9 \\
\hline IHL-305 & 50 & $0.06 \pm 0.01$ & $<0.01$ & $<0.01$ & 86.9 \\
\hline IHL-305 & 100 & $0.05 \pm 0.01$ & $<0.01$ & $<0.01$ & 89.1 \\
\hline CPT-11 & 25 & $0.35 \pm 0.13$ & N.S. & - & 23.6 \\
\hline CPT-11 & 50 & $0.35 \pm 0.04$ & N.S. & - & 24.5 \\
\hline CPT-11 & 100 & $0.35 \pm 0.05$ & N.S. & - & 24.0 \\
\hline
\end{tabular}

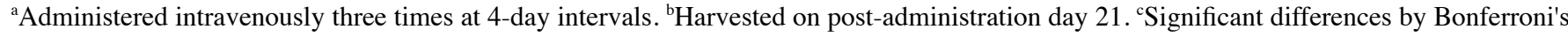
multiple comparison test. ${ }^{\mathrm{d}}$ Tumor growth inhibition rate. N.S., not significant.

Table II. Antitumor effect of IHL-305 and CPT-11 on human prostate cancer cell line PC-3 in nude mice.

\begin{tabular}{|c|c|c|c|c|c|}
\hline \multirow[b]{2}{*}{ Group } & \multirow[b]{2}{*}{ Total dose ${ }^{\mathrm{a}}(\mathrm{mg} / \mathrm{kg})$} & \multirow{2}{*}{$\begin{array}{l}\text { Tumor weight }^{\mathrm{b}} \\
(\mathrm{g}, \text { mean } \pm \mathrm{SD})\end{array}$} & \multicolumn{2}{|c|}{ p-value ${ }^{c}$ vs. } & \multirow[b]{2}{*}{$\operatorname{IR}^{\mathrm{d}}(\%)$} \\
\hline & & & Control & CPT-11 & \\
\hline Control & - & $1.26 \pm 0.18$ & - & - & - \\
\hline IHL-305 & 25 & $0.03 \pm 0.01$ & $<0.001$ & $<0.001$ & 97.9 \\
\hline IHL-305 & 50 & $0.02 \pm 0.00$ & $<0.001$ & $<0.001$ & 98.3 \\
\hline IHL-305 & 100 & $0.01 \pm 0.00$ & $<0.001$ & $<0.001$ & 99.0 \\
\hline CPT-11 & 25 & $0.64 \pm 0.25$ & $<0.001$ & - & 49.0 \\
\hline CPT-11 & 50 & $0.66 \pm 0.13$ & $<0.001$ & - & 48.0 \\
\hline CPT-11 & 100 & $0.48 \pm 0.20$ & $<0.001$ & - & 62.3 \\
\hline
\end{tabular}

${ }^{a}$ Administered intravenously three times at 4-day intervals. ${ }^{b}$ Harvested on post-administration day 21. 'Significant differences by Bonferroni's multiple comparison test. ${ }^{\mathrm{d}}$ Tumor growth inhibition rate.

Table III. Antitumor effect of IHL-305 and CPT-11 on human non-small cell lung cancer cell line QG-56 in nude mice.

\begin{tabular}{|c|c|c|c|c|c|c|}
\hline \multirow[b]{2}{*}{ Group } & \multirow[b]{2}{*}{ Total dose ${ }^{\mathrm{a}}(\mathrm{mg} / \mathrm{kg})$} & \multirow{2}{*}{$\begin{array}{l}\text { Tumor weight } \\
(\mathrm{g}, \text { mean } \pm \mathrm{SD})\end{array}$} & \multicolumn{2}{|c|}{ p-value ${ }^{\mathrm{c}}$ vs. } & \multirow[b]{2}{*}{$\operatorname{IR}^{\mathrm{d}}(\%)$} & \multirow[b]{2}{*}{ Cured mice } \\
\hline & & & Control & CPT-11 & & \\
\hline Control & - & $1.26 \pm 0.18$ & & - & - & - \\
\hline IHL-305 & 25 & $0.03 \pm 0.01$ & $<0.001$ & $<0.001$ & 97.9 & $0 / 5$ \\
\hline IHL-305 & 50 & $0.02 \pm 0.00$ & $<0.001$ & $<0.001$ & 98.3 & $0 / 5$ \\
\hline IHL-305 & 100 & $0.01 \pm 0.00$ & $<0.001$ & $<0.001$ & 99.0 & $1 / 5$ \\
\hline CPT-11 & 25 & $0.64 \pm 0.25$ & $<0.001$ & - & 49.0 & $0 / 5$ \\
\hline CPT-11 & 50 & $0.66 \pm 0.13$ & $<0.001$ & - & 48.0 & $0 / 5$ \\
\hline CPT-11 & 100 & $0.48 \pm 0.20$ & $<0.001$ & - & 62.3 & $0 / 5$ \\
\hline
\end{tabular}

${ }^{a}$ Administered intravenously three times at 4-day intervals. ${ }^{\mathrm{b} H a r v e s t e d ~ o n ~ p o s t-a d m i n i s t r a t i o n ~ d a y ~ 21 . ~ ' S i g n i f i c a n t ~ d i f f e r e n c e s ~ b y ~ B o n f e r r o n i ' s ~}$ multiple comparison test. ${ }^{\mathrm{d}}$ Tumor growth inhibition rate.

Antitumor effect of IHL-305 on various dosing schedules. The tumor growth inhibitory effect of IHL-305 on various dosing schedules was further investigated using HCT116-bearing nude mice (Table IV). The administration dose of IHL-305 was set at a total dose of $27 \mathrm{mg} / \mathrm{kg}$ as CPT-11, which is $1 / 10$ of MTD dosing of CPT-11, so, that we could confirm the differ- 
$\mathbf{A}$

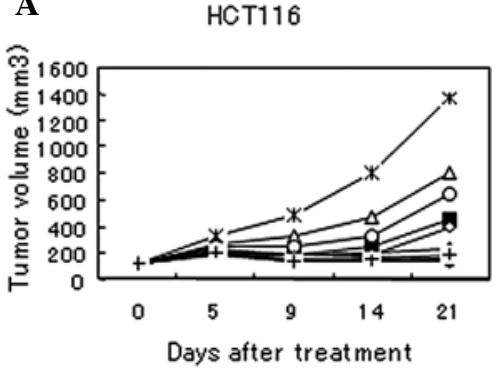

HT-29

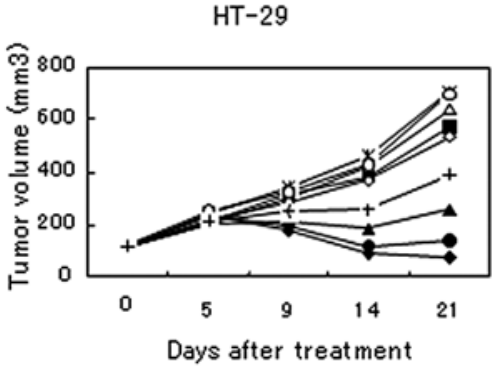

NCI-H460

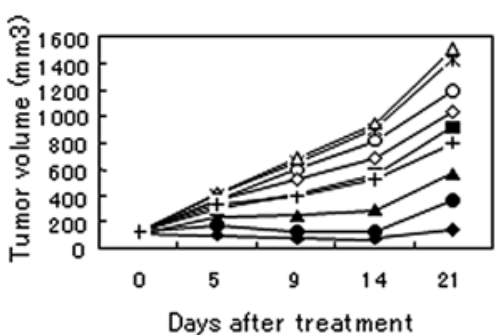

B

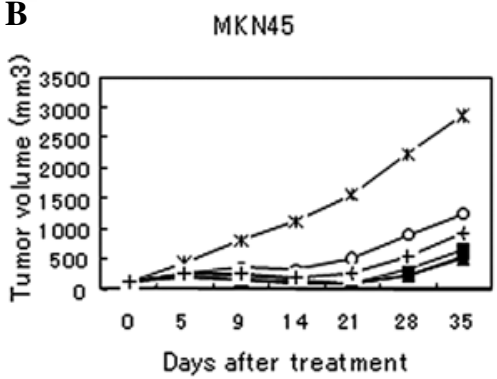

NCI-H82

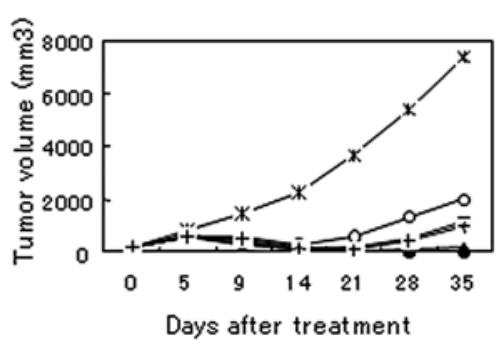

ES-2

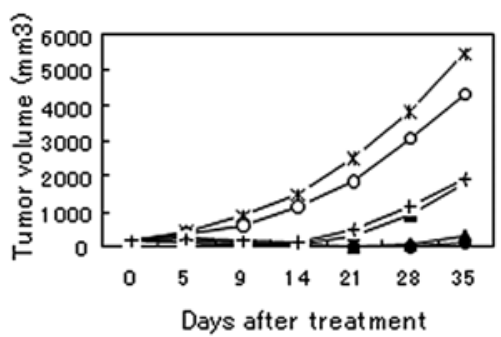

Figure 2. Antitumor activity of IHL-305 and CPT-11 against several human xenografts. After HCT116, HT-29, NCI-H460, MKN-45, NCI-H82 or ES-2 were inoculated subcutaneously into nude mice, the mice were grouped (6-10 mice/group) on the day when their mean estimated tumor volume reached about $120-220 \mathrm{~mm}^{3}$ (Day 0). IHL-305 (-, $16.875 \mathrm{mg} / \mathrm{kg} ; \boldsymbol{\square}, 33.75 \mathrm{mg} / \mathrm{kg} ; \boldsymbol{\Lambda}, 67.5 \mathrm{mg} / \mathrm{kg} ; \bullet, 1135 \mathrm{mg} / \mathrm{kg}$ ) and CPT-11 (口, $33.75 \mathrm{mg} / \mathrm{kg} ; \Delta, 67.5 \mathrm{mg} / \mathrm{kg} ;$ ○, $135 \mathrm{mg} / \mathrm{kg} ;$ ,$+ 270 \mathrm{mg} / \mathrm{kg}$ ) were administered intravenously on Days 1,5 and 9, and the long and short diameter of tumors were monitored. Control (*) was injected with saline. (A) 21-day observation period, (B) 35-day observation period.

Table IV. Antitumor effect of IHL-305 at various dosing schedules in HCT116-bearing nude mice.

\begin{tabular}{|c|c|c|c|c|c|}
\hline Group & Dosing schedule ${ }^{a}$ & Total dose $(\mathrm{mg} / \mathrm{kg})$ & $\begin{array}{c}\text { Tumor weight }^{b} \\
(\text { mean } \pm \mathrm{SD})\end{array}$ & p-value ${ }^{c}$ & Inhibition rate $(\%)$ \\
\hline Control & - & - & $1.23 \pm 0.14$ & - & - \\
\hline Empty liposome & $1,5,9$ & - & $1.29 \pm 0.40$ & - & -5.1 \\
\hline IHL-305 & $1,5,9$ & 27 & $0.27 \pm 0.03$ & $<0.001$ & 77.8 \\
\hline IHL-305 & $1,8,15$ & 27 & $0.29 \pm 0.07$ & $<0.001$ & 76.7 \\
\hline IHL-305 & 1,5 & 27 & $0.30 \pm 0.09$ & $<0.001$ & 75.9 \\
\hline IHL-305 & 1,8 & 27 & $0.32 \pm 0.17$ & $<0.001$ & 74.1 \\
\hline IHL-305 & 1,15 & 27 & $0.41 \pm 0.05$ & $<0.001$ & 66.8 \\
\hline IHL-305 & 1 & 27 & $0.45 \pm 0.15$ & $<0.001$ & 63.1 \\
\hline CPT-11 & $1,5,9$ & 270 & $0.23 \pm 0.07$ & $<0.001$ & 81.6 \\
\hline
\end{tabular}

${ }^{\mathrm{a} A d m i n i s t e r e d ~ i n t r a v e n o u s l y ; ~}{ }^{\mathrm{b}}$ arvested on post-administration day $21 .{ }^{\mathrm{c}}$ Significant differences by Dunnett's multiple comparison test.

ences between the various dosing schedules. After grouping on Day 0, IHL-305 was administered i.v. to tumor-bearing mice on Days 1, 5, 9; Days 1, 8, 15; Days 1, 5; Days 1, 8; Days
1, 15; and Day 1. Control groups received physiological saline, empty liposomes or CPT-11 (total dose, $270 \mathrm{mg} / \mathrm{kg}$; MTD) on Days $1,5,9$, and the IR of tumor growth was calculated 
A

HCT116

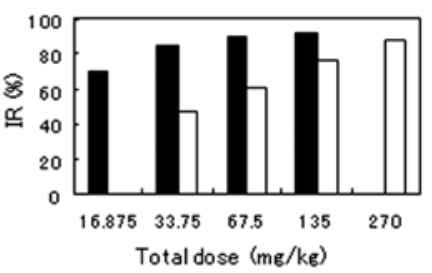

HT-29

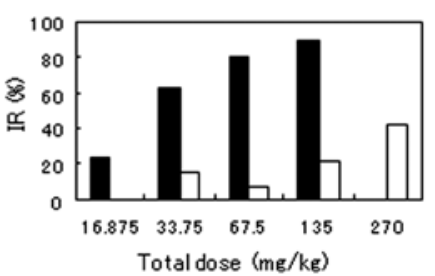

$\mathrm{NCI}-\mathrm{H} 460$

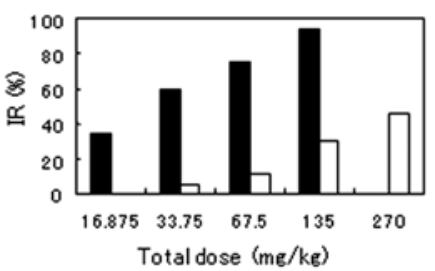

B

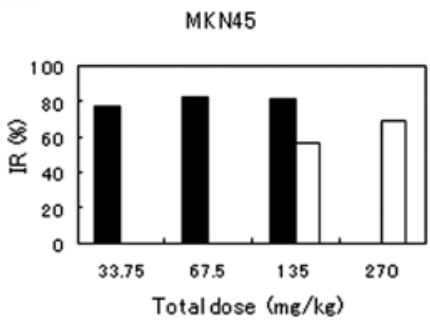

NCI-H82

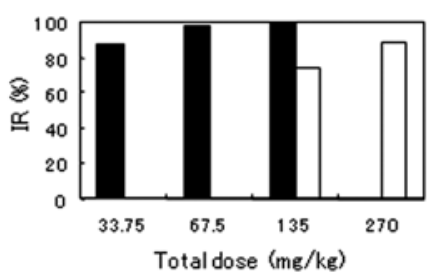

ES-2

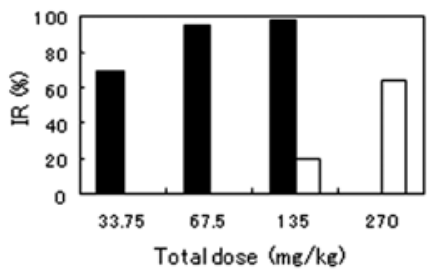

Figure 3. Inhibition rate of IHL-305 and CPT-11 on several human xenografts. After HCT116, HT-29, NCI-H460, MKN-45, NCI-H82 or ES-2 (2-5x10 ${ }^{6}$ cells/ mouse) was inoculated subcutaneously into nude mice, the mice were grouped (5-10 mice/group) on the day when their mean estimated tumor volume reached

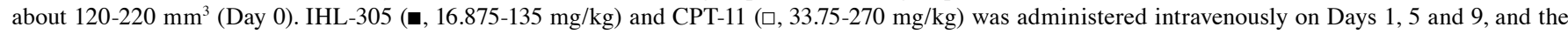
inhibition rate (IR\%) of tumor growth was calculated from tumor weights on Day 21 (A) or Day 35 (B).

A
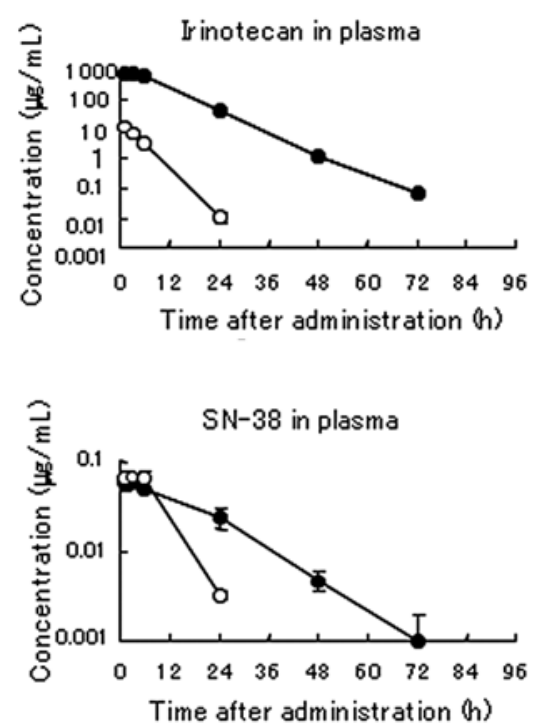

B
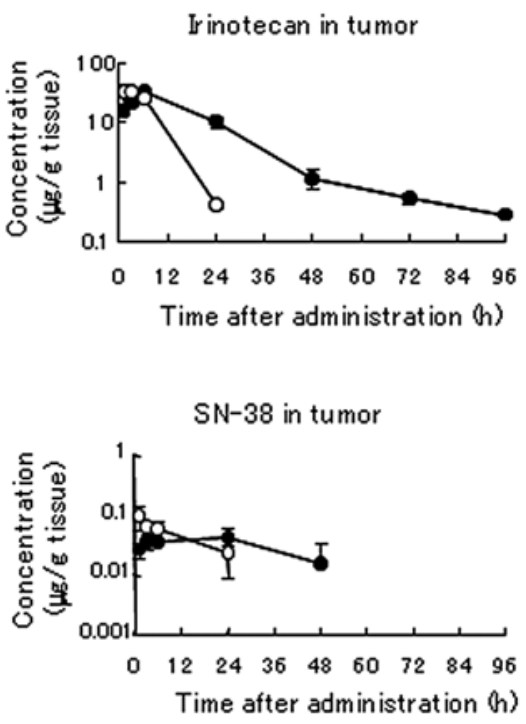

Figure 4. Measurement of CPT-11 and SN-38 in plasma and tumors. HT-29 (2x10 cells/mouse) was inoculated subcutaneously into nude mice on Day 0. The mice were grouped (3 mice/1 point/group) on Day 12 when the mean estimated tumor volume had reached about 430 mm ${ }^{3}$ and IHL-305 (•, 45 mg/kg) and CPT-11 (O, $90 \mathrm{mg} / \mathrm{kg})$ was administered intravenously. The plasma and tumors were collected for $96 \mathrm{~h}$ and the concentrations of CPT-11 and SN-38 were measured with HPLC as described in Materials and methods. Data represent the mean \pm SD of 3 animals.

from tumors excised and weighed on Day 21. The IR of the tumor growth in animals which received empty liposomes was $-5.1 \%$, indicating no antitumor effect. However, the tumor weight in all IHL-305 groups differed significantly $(\mathrm{p}<0.001)$ compared with the control group, and the tumor growth IR was high (63.1-77.8\%). When IHL-305 was administered 1, 2, 
or 3 times with dosing intervals of 4 , 7, or 14 days, a similar IR in the IHL-305 group was seen for 3 administrations (76.7$77.8 \%)$ and 2 administrations $(66.8,75.9 \%)$; a slightly lower rate $(63.1 \%)$ was seen for 1 administration. The IR was similar when the dosing interval was 4 days (75.9-77.8\%) and 7 days (74.1-76.7\%), but was slightly lower $(66.8 \%)$ when the interval was 14 days. Overall, the tumor weight was significantly lower $(p<0.001)$ in all groups receiving IHL-305 as compared with the control group, indicating that IHL-305 was effective for controlling the growth of HCT116 transplanted to nude mice by all dosing schedules examined in this study.

Concentrations of irinotecan and SN-38 in plasma and tumors. To examine the difference of the inhibitory effect between IHL-305 and CPT-11, the concentrations of irinotecan and SN-38 in plasma and tumors after i.v. injection of both drugs were measured. As indicated in Fig. 4A, the irinotecan concentration in plasma after IHL-305 injection (45 mg/kg) was maintained constantly until $3 \mathrm{~h}$ after injection, followed by an exponential decrease until $72 \mathrm{~h}$, whereas the irinotecan concentration after CPT-11 injection $(90 \mathrm{mg} /$ $\mathrm{kg}$ ) had decreased exponentially by $24 \mathrm{~h}$ although the dose in the irinotecan group was twice that of the CPT-11 group. The SN-38 concentration in plasma after IHL-305 injection was almost the same as that after CPT-11 injection at the maximum concentration, however, the disappearance of SN-38 in IHL-305 treated mice was apparently slower than that in CPT-11-treated mice and maintenance of SN-38 levels in the IHL-305 group was observed for $72 \mathrm{~h}$ after the injection. On the other hand, the intratumoral irinotecan concentration after IHL-305 injection peaked at $6 \mathrm{~h}$ after injection, and then decreased gradually until $96 \mathrm{~h}$ post-injection, whereas after CPT-11 injection it demonstrated constant maintenance until $3 \mathrm{~h}$ post-injection, followed by a rapid decrease by $24 \mathrm{~h}$. The maximum post-injection intratumoral concentration of SN-38 of each drug was similar (Fig. 4B). The SN-38 concentration in tumors after IHL-305 injection was maintained at a certain level until $24 \mathrm{~h}$ after injection, and then decreased gradually by $48 \mathrm{~h}$, whereas that after CPT-11 injection decreased consecutively after $1 \mathrm{~h}$ post-injection. SN-38 was still at detectable levels at $48 \mathrm{~h}$ after injection of IHL-305, but this was not the case with CPT- 11 .

\section{Discussion}

In this study, we examined the antitumor profile of a newly formulated pegylated liposome preparation, IHL-305, using nude mice subcutaneously inoculated with 8 kinds of human xenografts. Since CPT-11 has been reported to possess antitumor activity against human xenografts (30), it was expected that greater effects of IHL-305 would be shown in tumorbearing mice. As the overall results demonstrated, IHL-305 showed successful antitumor activities against all xenografts tested.

In the first study, we compared the antitumor effect of IHL-305 to that of CPT-11 against human colorectal, prostate and non-small cell lung cancers over a 21-day period. The results showed that IHL-305 demonstrated significant tumor growth inhibitory effects in all tumors tested in spite of the quite low dosage compared with irinotecan. When compari- sons were made at the same dose level in this study, tumor weight was significantly lower in the IHL-305 group than in the corresponding CPT-11 group. These results indicated that IHL-305 possesses a higher potential to suppress the tumor growth of xenografts at low doses compared to CPT-11. In particular, IHL-305 exhibited strong antitumor activity against the HT-29 colorectal cancer cell line which is recognized as having an intrinsic resistance to chemotherapeutic agents including CPT-11 $(25,31)$. Although CPT-11 is reported to show antitumor activity against multidrug-resistant tumors both in vitro and in vivo (32), detailed investigations as to the overcoming of drug-resistance of IHL-305 are in progress. Moreover, neither drug had much impact on changes in body weight. These observations were in concordance with the reports that liposomes containing PEG have been shown to reduce toxic side effects such as body weight loss and can up-regulate the MTD of the drugs with a better therapeutic profile compared with CPT-11 $(12,28)$.

Having confirmed the antitumor efficacy of IHL-305 over the 21-day period, we then planned further experiments over longer periods of observation with various human xenografts. In this series of experiments, the maximum dose of CPT-11 as the reference was set at the MTD so that an equal comparison with IHL-305 could be performed for the 21- or 35-day observation. Since the MTD of IHL-305 was not able to be calculated ( $>600 \mathrm{mg} / \mathrm{kg}$ in rats), the maximum dose of IHL-305 was set at one-half that of CPT-11 based on the characteristic of a liposome preparation that it does not need more than the original drug. IHL-305 was seen to have strong antitumor activity on all tumors tested even in the 35-day observation period. Comparison of the inhibition rate (IR) between IHL-305 and CPT-11 at the same dose clearly demonstrated that IHL-305 showed a higher IR and produced a comparable tumor growth inhibitory effect at doses from one-half to one-eighth that of CPT-11 even in HT-29- and NCI-H460-bearing mice, which are relatively resistant to CPT-11. These results demonstrated the long-lasting effect with a low dose of IHL-305 as one of the characteristics of liposome preparation, as described elsewhere $(13,33)$.

Further examinations were made of the IHL-305 dosing schedules, which revealed that IHL-305 exhibited successful antitumor effect at all time periods tested, i.e. intervals of 4-14 days, indicating that IHL-305 will be easy to use or handle for various schedules. Liposome preparations are often used and evaluated with many dosing frequencies, such as 5 consecutive administrations, in animal experiments $(13,18,25)$. However, our results suggest that IHL-305 could be used with a lower dosing frequency and at lower dosages compared with CPT-11.

To investigate the difference of the IR between IHL-305 and CPT-11 at the optimal dose in HT-29-bearing mice, we measured the concentrations of irinotecan and SN-38 in the plasma and tumors after i.v. injection of both drugs. The higher concentration of irinotecan in plasma in the IHL-305 group compared with the CPT-11 group lasted for $72 \mathrm{~h}$ after the injection of IHL-305, while the concentration of irinotecan in the CPT-11 group had reduced rapidly by $24 \mathrm{~h}$ after injection of CPT-11, even though the CPT-11 dosage was double that of IHL-305. On the other hand, the peak concentration level of SN-38 was almost the same in both groups just after the 
injection, but the levels of SN-38 in the IHL-305 group were maintained for $72 \mathrm{~h}$ after the injection. The same tendency as described above was observed in tumors after administration of each drug. From the pharmacokinetic analysis, it was speculated that the extension of the retention time of SN-38 in the tumor was due to the slow release of irinotecan from the IHL-305 liposomes distributed in the tumor, because the retention time of SN-38 in tumors was almost the same in both groups. These results indicated that the difference of the inhibitory effect between IHL-305 and CPT-11 depended on the maintenance of the concentrations of irinotecan and SN-38 in HT-29-bearing mice. However, further study will be required to clarify the detailed profile of the kinetics of IHL-305 in tumor-bearing mice.

In conclusion, we demonstrated the efficacy of a pegylated liposome preparation, IHL-305, in several human xenograft models. IHL-305 was shown to possess a wide range of antitumor spectra against several human tumors. It was also indicated that the antitumor activity of IHL-305 exceeded that of CPT-11 in terms of animal experiments and could thus be expected to be used as a replacement for CPT-11. IHL-305 may provide a potential therapeutic tool for the treatment of human cancers. Clinical trial of IHL-305 is now in progress.

\section{Acknowledgements}

The authors thank Dr Hiroshi Nagata for support in the statistical analysis, and the safety research team in our institute for animal care.

\section{References}

1. Sawada S, Okajima S, Aiyama R, Nokata K, Furuta T, Yokokura T, Sugino E, Yamaguchi K and Miyasaka T: Synthesis and antitumor activity of 20(S)-camptothecin derivatives: carbamate-linked, water-soluble derivatives of 7-ethyl-10-hydroxycamptothecin Chem Pharm Bull (Tokyo) 39: 1446-1450, 1991.

2. Jansen WJ, Zwart B, Hulscher ST, Giaccone G, Pinedo HM and Boven E: CPT-11 in human colon-cancer cell lines and xenografts: characterization of cellular sensitivity determinants. Int J Cancer 70: 335-340, 1997.

3. Tsunoda T, Tanimura H, Hotta T, Tani M, Iwahashi M, Tanaka H, Matsuda $\mathrm{K}$ and Yamaue $\mathrm{H}$ : In vitro antitumor effect of topoisomerase-I inhibitor, CPT-11, on freshly isolated human gastric and colorectal cancer. Anticancer Res 19: 5451-5455, 1999.

4. Kunimoto T, Nitta K, Tanaka T, Uehara N, Baba H, Takeuchi M, Yokokura T, Sawada S, Miyasaka T and Mutai M: Antitumor activity of 7-ethyl-10-[4-(1-piperidino)-1-piperidino] carbonyloxy-camptothecin, a novel water-soluble derivative of camptothecin, against murine tumors. Cancer Res 47: 5944-5947, 1987.

5. Matsuzaki T, Yokokura T, Mutai M and Tsuruo T: Inhibition of spontaneous and experimental metastasis by a new derivative of camptothecin, CPT-11, in mice. Cancer Chemother Pharmacol 21: 308-312, 1988.

6. André T, Louvet C, Maindrault-Goebel F, Couteau C, Mabro M, Lotz JP, Gilles-Amar V, Krulik M, Carola E, Izrael V and de Gramon A: CPT-11 (irinotecan) addition to bimonthly, high-dose leucovorin and bolus and continuousinfusion 5-fluorouracil (FOLFIRI) for pretreated metastatic colorectal cancer. GERCOR. Eur J Cancer 35: 1343-1347, 1999.

7. Saltz LB, Cox JV, Blanke C, Rosen LS, Fehrenbacher L, Moore MJ, Maroun JA, Ackland SP, Locker PK, Pirotta N, Elfring GL and Miller LL: Irinotecan plus fluorouracil and leucovorin for metastatic colorectal cancer. Irinotecan Study Group. N Engl J Med 343: 905-914, 2000.
8. Souglakos J, Pallis A, Kakolyris S, Mavroudis D, Androulakis N, Kouroussis C, Agelaki S, Xenidis N, Milaki G and Georgoulias V: Combination of irinotecan (CPT-11) plus 5-fluorouracil and leucovorin (FOLFIRI regimen) as first line treatment for elderly patients with metastatic colorectal cancer: a phase II trial. Oncology 69: 384-390, 2005.

9. Bleiberg H: CPT-11 in gastrointestinal cancer. Eur J Cancer 35: 371-379, 1999.

10. Alimonti A, Gelibter A, Pavese I, Satta F, Cognetti F, Ferretti G, Rasio D, Vecchione A and Di Palma M: New approaches to prevent intestinal toxicity of irinotecan-based regimens. Cancer Treat Rev 30: 555-562, 2004.

11. Raymond E, Boige V, Faivre S, Sanderink GJ, Rixe O, Vernillet L, Jacques C, Gatineau M, Ducreux M and Armand JP: Dosage adjustment and pharmacokinetic profile of irinotecan in cancer patients with hepatic dysfunction. J Clin Oncol 20: 4303-4312, 2002.

12. Sadzuka Y, Hirotsu S and Hirota S: Effect of liposomalization on the antitumor activity, side-effects and tissue distribution of CPT-11. Cancer Lett 127: 99-106, 1998.

13. Pal A, Khan S, Wang YF, Kamath N, Sarkar AK, Ahmad A, Sheikh S, Ali S, Carbonaro D, Zhang A and Ahmad I: Preclinical safety, pharmacokinetics and antitumor efficacy profile of liposome-entrapped SN-38 formulation. Anticancer Res 25: 331-341, 2005.

14. Harigai T, Kondo M, Isozaki M, Kasukawa $\mathrm{H}$, Hagiwara $\mathrm{H}$, Uchiyama $\mathrm{H}$ and Kimura $\mathrm{J}$ : Preferential binding of polyethylene glycol-coated liposomes containing a novel cationic lipid, TRX-20, to human subendthelial cells via chondroitin sulfate. Pharm Res 18: 1284-1290, 2001.

15. Fang J, Sawa T and Maeda H: Factors and mechanism of 'EPR' effect and the enhanced antitumor effects of macromolecular drugs including SMANCS. Adv Exp Med Biol 519: 29-49, 2003.

16. Tanaka T, Shiramoto S, Miyashita M, Fujishima Y and Kaneo Y: Tumor targeting based on the effect of enhanced permeability and retention (EPR) and the mechanism of receptor-mediated endocytosis (RME). Int J Pharm 277: 39-61, 2004.

17. Reddy LH: Drug delivery to tumours: recent strategies. J Pharm Pharmacol 57: 1231-1242, 2005.

18. Mayhew EG, Goldrosen MH, Vaage J and Rustum YM: Effects of liposome-entrapped doxorubicin on liver metastases of mouse colon carcinomas 26 and 38. J Natl Cancer Inst 78: 707-713, 1987.

19. Vaage J, Mayhew E, Lasic D and Martin F: Therapy of primary and metastatic mouse mammary carcinomas with doxorubicin encapsulated in long circulating liposomes. Int J Cancer 51: 942-948, 1992.

20. Tsukioka Y, Matsumura Y, Hamaguchi T, Koike H, Moriyasu F and Kakizoe T: Pharmaceutical and biomedical differences between micellar doxorubicin (NK911) and liposomal doxorubicin (Doxil). Jpn J Cancer Res 93: 1145-1153, 2002.

21. Lee CM, Tanaka T, Murai T, Kondo M, Kimura J, Su W, Kitagawa T, Ito T, Matsuda H and Miyasaka M: Novel chondroitin sulfate-binding cationic liposomes loaded with cisplatin efficiently suppress the local growth and liver metastasis of tumor cells in vivo. Cancer Res 62: 4282-4288, 2002.

22. Sharma A and Straubinger RM: Novel taxol formulations: preparation and characterization of taxol-containing liposomes. Pharm Res 11: 889-896, 1994.

23. Crosasso P, Ceruti M, Brusa P, Arpicco S, Dosio F and Cattel L: Preparation, characterization and properties of sterically stabilized paclitaxel-containing liposomes. J Control Release 63: 19-30, 2000.

24. Sadzuka Y, Hirotsu S and Hirota S: Effective irinotecan (CPT-11)-containing liposomes: intraliposomal conversion to the active metabolite SN-38. Jpn J Cancer Res 90: 226-232, 1999.

25. Lei S, Chien PY, Sheikh S, Zhang A, Ali S and Ahmad I: Enhanced therapeutic efficacy of a novel liposome-based formulation of SN-38 against human tumor models in SCID mice. Anticancer Drugs 15: 773-738, 2004.

26. Bourgeois H, Ferru A, Lortholary A, Delozier T, BoisdronCelle M, Abadie-Lacourtoisie S, Joly F, Chieze S, Chabrun V, Gamelin E and Tourani JM: Phase I-II study of pegylated liposomal doxorubicin combined with weekly paclitaxel as firstline treatment in patients with metastatic breast cancer. Am J Clin Oncol 29: 267-275, 2006.

27. Bourgeois H, Joly F, Pujade-Lauraine E, Cure H, Guastalla JP, Ferru A, Chabrun V, Chieze S and Tourani JM: Phase I study of pegylated liposomal doxorubicin in combination with ifosfamide in pretreated ovarian cancer patients. Am J Clin Oncol 29: $399-404,2006$ 
28. Gabizon A, Catane R, Uziely B, Kaufman B, Safra T, Cohen R, Martin F, Huang A and Barenholz Y: Prolonged circulation time and enhanced accumulation in malignant exudates of doxorubicin encapsulated in polyethylene-glycol coated liposomes. Cancer Res 54: 987-992, 1994

29. Kurita A and Kaneda N: High-performance liquid chromatographic method for the simultaneous determination of the camptothecin derivative irinotecan hydrochloride, CPT-11, and its metabolites $\mathrm{SN}-38$ and $\mathrm{SN}-38$ glucuronide in rat plasma with a fully automated on-line solid-phase extraction system, PROSPEKT. J Chromatogr B Biomed Sci Appl 724: 335-344, 1999.

30. Kawato Y, Furuta T, Aonuma M, Yasuoka M, Yokokura T and Matsumoto K: Antitumor activity of a camptothecin derivative, CPT-11, against human tumor xenografts in nude mice. Cancer Chemother Pharmacol 28: 192-198, 1991.
31. Azrak RG, Cao S, Slocum HK, Tóth K, Durrani FA, Yin MB, Pendyala L, Zhang W, McLeod HL and Rustum YM: Therapeutic synergy between irinotecan and 5-fluorouracil against human tumor xenografts. Clin Cancer Res 10: 1121-1129, 2004.

32. Tsuruo T, Matsuzaki T, Matsushita M, Saito H and Yokokura T: Antitumor effect of CPT-11, a new derivative of camptothecin, against pleiotropic drug-resistant tumors in vitro and in vivo. Cancer Chemother Pharmacol 21: 71-74, 1988

33. Mayhew EG, Lasic D, Babbar S and Martin FJ: Pharmacokinetics and antitumor activity of epirubicin encapsulated in long-circulating liposomes incorporating a polyethylene glycol-derivatized phospholipid. Int J Cancer 51: 302-309, 1992. 